2009

\title{
World Social Forum 2009: Time to Bring the WSF to the USA
}

Ponniah

Follow this and additional works at: https://scholarlycommons.law.case.edu/swb

Part of the Human Rights Law Commons, and the Social and Behavioral Sciences Commons

\section{Recommended Citation}

Ponniah. 2010. "World Social Forum 2009: Time to Bring the WSF to the USA." Societies Without Borders 4 (2): 254-260. Available at: https://scholarlycommons.law.case.edu/swb/vol4/iss2/11

This Article is brought to you for free and open access by the Cross Disciplinary Publications at Case Western Reserve University School of Law Scholarly Commons. It has been accepted for inclusion in Societies Without Borders by an authorized administrator of Case Western Reserve University School of Law Scholarly Commons. 


\title{
World Social Forum 2009: Time to Bring the WSF to the USA
}

\author{
Thomas Ponniah \\ Harvard University
}

Submitted 10 March 2009; accepted 20 March 2009

\begin{abstract}
I had the opportunity to both attend the Inauguration of the 44th President of the United States and to participate in the World Social Forum hosted in Belém, Brazil. ${ }^{1}$ The Inaugural was attended by 1.8 million citizens, which included a notably large percentage of AfricanAmericans, from all over the country. The World Social Forum had over 133,000 participants from around the world with a substantial number of Pan-Amazonic social movements. In both cases I witnessed a mobilized, dynamic civil sphere aspiring to a new, better society. The key to achieving another world is to bring these spheres together.
\end{abstract}

\section{Keywords}

U.S. Presidential Inauguration, World Social Forum, civil sphere, society

\section{The Inauguration}

I landed at Baltimore's Thurgood Marshall airport on January 19th - Martin Luther King Day - a national holiday celebrated throughout most of the United States. Surprisingly the U.S. Transport Security Administration had set up a small exhibit in the airport on the Civil Rights Movement. I sat down and watched an hour of videos chronicling the activism of one of the U.S.'s most inspirational social mobilizations. It was stirring to see the different sides of the movement: the Montgomery Bus Boycott, the Poor People's Campaign, and of course the dazzling, timeless speech at the Washington monument. King's message was eternal because it restated in a new language, as every generation does, the essence of the progressive vision.

1) Thanks to Marc Becker for his comments on a previous draft of this essay. 
The night before the Inauguration I was asked to speak at a dinner party hosted by Andrew Miller - an environmentalist who was also going to the Amazon for WSF 2009. The topic of my discussion was the proposals for an alternative globalization proposed at the Forum. However I could not help but bring up the fact of King's birthday and its relation to the event that we would all see the next day. From a young age, my father - James Ponniah - who lived in the U.S. when King was assassinated - had raised me on a perpetual stream of stories about the 1960's: King, Malcolm X, Robert Kennedy, and Angela Davis were names that I regularly heard. He, like many who supported Obama, interpreted this recent U.S. election as the political, though not economic, culmination of the Civil Rights movement.

On Inauguration Day, the streets were inundated with people and being the U.S. - products. There were King and Obama posters, t-shirts, berets, buttons, superhero dolls ("an action figure that you can trust") and even air fresheners. While critical of consumerism one could not help but be caught up in the collective effervescence. The person who best understood the rapture was of course the rock star himself. Obama's address, though not comparable to his earlier, innovative campaign speeches on religion and race, emphasized accountability: the U.S. public had to take responsibility for the failure of the past and the promise of the future. It was a speech that touched on the most heroic side of the country's tradition, calling for social change that was grounded in the ideals once noted by Alexis de Tocqueville. The French writer had written that what distinguished U.S. democracy was its public participation. ${ }^{2}$ Obama's speech was an appeal for public engagement, responsibility and vision.

Now momentous events in the U.S. are not only embodied by a surfeit of new consumer goods but also by the approval of the country's aristocracy. In contrast to most countries, and centuries, the U.S.' nobility are not economic elites but instead popular cultural ones. That evening the Obamas attended ten inaugural balls. The first, the Neighborhood Ball, was attended by Hollywood actors and pop stars such as Shakira, Jay-Z, Faith Hill, and Beyoncé. The latter sung the Etta James classic "At Last" - a popular tune usually played at weddings across the country. The song was an opportunity for the Obamas to have their "first dance" as the First Couple. At the end of her performance the singer was asked by the $\mathrm{ABC}$ reporter what this event meant to her. She replied, "It's probably the most important day of my life... He makes me want to be smarter, he makes me want to be more

\footnotetext{
2) See de Tocqueville 1969 .
} 
involved." Her response echoed the sentiments that I had seen and heard all day in Washington - whether I was speaking with progressives over dinner, on the subways, or at the Washington monument. The Inauguration of Obama represented the possibility for a broad-based renewal of the U.S. public sphere.

\section{WSF 2009}

A week later I flew to the Brazilian Amazon to attend the 2009 edition of the World Social Forum (WSF). The Forum first emerged in 2001 out of a cycle of protest oriented around the latest form of globalization - most famously in the massive protests in Seattle against the World Trade Organization. The first Forum was held simultaneous to the World Economic Forum annually held in Davos, Switzerland. The WSF's goals were to have a meeting place where activists from around the planet could propose alternatives to "neoliberal" or free market globalization. The Forums have been held in different parts of the world such as India, Venezuela, Mali, Pakistan, and Kenya, but primarily in the home of its founding movements - Brazil. The Forums have regularly hosted tens of thousands of participants attending workshops, seminars, panels, and artistic events. The popular slogan of the Forum "Another World is Possible" has become our generation's way of stating "I Have a Dream."

The choice to hold the Forum in the Amazon was a political decision. At no other point in history has the global public been more aware of the danger posed to the environment by the instrumental rationality of the modern system. The first day of workshops was dedicated to Pan-Amazonic movements. Social movements of all varieties converged on this event with one key idea running through all of them: the current model of civilization was in crisis because it had severed itself from Life. ${ }^{3}$ The choice of the Amazon as the site for the Forum was to highlight what many indigenous movements had been saying for decades: our actions are damaging the Earth, nature-society relations and ourselves. The future of humanity, they argued, now depends on an entirely new conceptual, practical and expressive relationship with Nature and each other. Perhaps nothing symbolized this sentiment better than the beautiful, checkered rainbow flag, the Wiphala, seen throughout the indigenous tent.

3) This point was made at a panel held in the "Indigenous Tent" on January 31 st. 
Curiously, an equally arresting group of political actors, holding the necessary, though not sufficient, solution to the above, stood just outside the Forum. On January 29th the leaders of Ecuador, Paraguay, Bolivia, and Venezuela held a "dialogue" with social movements and later that evening Presidents Morales, Chavez, Correa, Lugo, joined by Lula, spoke at an ecstatic event organized by the Brazilian Workers' Party at the Hangar an old airplane building that has been converted into a state of the art auditorium. Both the first and second events were electrifying occasions with rapt, chanting crowds. While political leaders are not invited into the Forum, the WSF has regularly had politicians, usually Chavez, come and speak outside the grounds, highlighting their fidelity to the content though not always the process being espoused. The first event ended with the Presidents all singing the haunting: "Hasta Siempre." The song became all the more poignant when Aleida Guevara, the daughter of the twentieth century's most famous revolutionary, came onto the stage and sang with the leaders.

The enthusiastic reception of the leaders, and the fact that one of the main groups that invited them, IBASE (Instituto Brasileiro de Análises Sociais e Econômicas), was one of the original members of the Brazilian Organizing Committee of the WSF - represents a growing understanding that social movements have to engage with state actors.

\section{Social Movements and the State}

The Forum arose in 2001 in a context in which social movements were strong but progressive state actors were weak. Immanuel Wallerstein has noted that the 1990s marked the breakdown of three prominent leftist projects: in the First World the welfare state was substantially undermined, in the Second World Soviet Communism fell, and in the Third World national liberation projects were met with increasing disillusionment. ${ }^{4}$ Corresponding to the exhaustion of these state projects, there was an acceleration of dispersed single-issue movements often oriented around the politics of identity such as gender, race, and sexuality. The Forum emerged in this context with an Open Space concept, that is, a mechanism that would allow various movements to identify themselves as having similar interests without necessarily agreeing on one collective program. Since

\footnotetext{
4) Wallerstein 2003.
} 
then we have seen the beginnings of an "inter-movement dialogue" across various sets of social actors. The Open Space has acted as a global communication infrastructure opening up the possibility for what Samir Amin has called a "convergence of difference" oriented around global justice coalitions, such as the World March of Women, that are organized across ideology, region and scale. Along with the articulation of an overarching common identity of difference and the creation of new networks, the Forum's other great achievement has been to give global social movements an opportunity to debate radically democratic alternatives to the modern system.

The present context however is very different from that of the Forum's emergence in 2001. Today, progressive state actors are not weak. The rise of the left in Latin America, and the election of the potentially most progressive U.S. presidency in thirty years, all point to the possibility of more humane state policies. As well, the differences amongst social movements seem much less pronounced. Years of dialogue, information sharing and collective mobilization via the Social Forum process has produced new hybrid movements as opposed to the single issue mobilizations of the past thirty years. In the context of new innovative political formations, it is not surprising that World Social Forum actors are arranging discussions with political parties just outside the perimeter of the Forum.

Social movements have the capacity to mobilize protest, such as the worldwide mobilization against the war on Iraq on February 15, 2003, to a far greater degree than political parties. However political actors, such as the Spanish Socialist government have the power to actually stop their involvement in the war, as they did when they were first elected in 2004. Social movements of the left need not abandon state power. The state is a crucial instrument for advancing the goals of progressives. Conservative social movements, even libertarians, have always understood state power as a powerful tool for their goals. They have never misunderstood the importance of using all the devices at one's disposal when attempting to advance a social project. Progressives should learn from this. While the state should not be embraced with any hopes of romance, it should be recognized, as King and Guevara understood, for the resources it can provide.

\section{The WSF and the USA}

The Forum is often depicted as a space that does not produce one common social project. Its most critical supporters often disparage this Open Space 
methodology as ineffective. They contend that the plurality of proposals, minus a unified program, leads to a carnivalesque atmosphere that is ultimately more of a cultural experience, a global Woodstock, rather than a political event. ${ }^{5}$ The debate on the WSF is often framed as "space versus actor" with the former position most strongly advocated by one of the Forum's founding parents: Chico Whitaker, and the latter position famously promoted by another member of the International Council - Walden Bello. ${ }^{6}$ However, there may be a third way to view this debate. Rather than see the conflict as one between "space" and "actor" it may be more productive to recognize the Forum as an arena where the space is the political actor.

The selection of venue - whether Porto Alegre, Mumbai, Caracas, Bamako, Karachi, Nairobi or the Amazon - has always been a political choice. The sites were chosen as strategic arenas that would have beneficial effects to local and global social movements. Today the International Council must make a decision about the location of the next World Social Forum. Normally the Council has chosen a place located in the Global South. This has been politically astute: events in the North, rarely include the views of most of the planet. Holding the Forum in Africa, Asia and Latin America, has allowed, as Boaventura de Sousa Santos has noted, for the emergence of the diversity of movements, practices and epistemologies of the South. ${ }^{7}$ However the historical context has changed. It is time to for social movements to dialogue with state actors, and above all, to engage the public sphere of the most prominent state in the world. It is time for movements that want to change the world to come to the USA.

The election of Obama has opened up the potential for a democratic renewal of the United States. The social movements, especially the past civil rights organizations and the current anti-war ones, that gave birth to Obama want a more just, diverse, and sustainable United States. They represent the best side of the U.S. experiment. It would be a great boon to these mobilizations, and because of the country's position in the global system, to all movements around the planet if the World Social Forum came to the United States in 2011.

\footnotetext{
5) Bello 2007.

6) Whitaker 2007; Bello 2007; see also my reply to Bello and Whitaker: Ponniah 2007.

7) Santos 2006.
} 
There are of course numerous obstacles to this proposal. The Forum has been dedicated to developing collective mobilizations in the Global South hence the need for it to continue to be deployed in Africa, Asia and Latin America. As well there will be legal difficulties specifically in terms of getting visas for all of the social movements that would like to participate in the Forum. However, all of us who note these various objections and obstacles should not forget the central reason for the creation of the WSF: to create another, better world. In the context of a globally resurgent progressive movement, and a U.S. population hungry for alternatives, it is time for the World Social Forum to be held in the United States.

\section{References}

Bello, Walden. 2007, “The Forum at the Crossroads.” http://www.fpif.org/fpiftxt/4196.

Ponniah, Thomas. 2007. "The Meaning of the U.S. Social Forum: a reply to Chico Whitaker and Walden Bello's debate on the Open Space”: http://wsfic-strategies.blogspot. com/2007/08/thomas-ponniah-contribution-of-us.html.

Santos, Boaventura de Sousa 2006, The Rise of the Global Left: The World Social Forum and Beyond. London: Zed Books.

Tocqueville, Alexis de, Democracy in America, 1969. Translated by George Lawrence and edited by J.P. Mayer. New York: Harper and Row.

Wallerstein, Immanuel. The Decline of American Power. 2003. New York: The New Press.

Whitaker, Chico. 2007. "Crossroads do not always close roads (Reflection in continuity to Walden Bello).” http://www.wsflibrary.org/index.php/Crossroads_do_not_always_ close_roads. 
Copyright of Societies Without Borders is the property of Brill Academic Publishers and its content may not be copied or emailed to multiple sites or posted to a listserv without the copyright holder's express written permission. However, users may print, download, or email articles for individual use. 